\title{
Antitumor Activity of Beta Glucan Extract from Oyster Mushroom (Pleurotus ostreatus Jacq. P. Kum) on DMBA-Induced Breast Cancer in vivo
}

\author{
Ida Susanti ${ }^{\star 1,2}$, Heri Wibowo ${ }^{2}$, Nurjati Chairani Siregar ${ }^{3}$, \\ Suyanto Pawiroharsono ${ }^{4}$, and Frans D. Sujatna ${ }^{2}$
}

${ }^{1}$ Center for Agroindustrial Technology,

Agency for the Assessment and Application of Technology (BPPT), LAPTIAB, 611

BId - Puspiptek Serpong, Tangerang Selatan, Indonesia

${ }^{2}$ Department of Faculty of Medicine, University of Indonesia, JI. Salemba 10, Jakarta, Indonesia

${ }^{3}$ Department of Patology Anatomy, Faculty of Medicine, University of Indonesia, Jakarta, Indonesia

${ }^{4}$ Center for Bioindustrial Technology, Agency for the Assessment and Application of Technology (BPPT), LAPTIAB, 611 BId - Puspiptek Serpong,

Tangerang Selatan, Indonesia

\begin{abstract}
It has been indicated that beta glucan is potential for anticancer due to its activity as immunomodulator. The aim of this research was to study the antitumor activity of oyster mushroom's beta glucan in female rats induced with 7,12 Dimethylbenz(a)anthracene (DMBA) as cancer promotor. Experimental rats were divided into four groups which consist of control group, DMBA group and beta glucan-treated groups (with two different doses of 0.25 g. $\mathrm{kg}^{-1}$ and $1 \mathrm{~g} . \mathrm{kg}^{-1}$ ). Inhibition of carcinogenesis were demonstrated in beta glucan-treated group which showed lower case of tumor incidence than DMBA group. Total volume and numbers of tumor nodules in beta glucan-treated group were lower than DMBA group. Analysis of histopathology of tumor nodules showed that beta glucan-treated group had a lower score than DMBA group indicating less severity of tumor. In conclusion, beta glucan from oyster mushroom has antitumor activity on DMBA-induced breast cancer in vivo.
\end{abstract}

Keywords: beta glucan, Pleurotus ostreatus, carcinogenesis, immunomodulator, DMBA.

International Journal of PharmTech Research, 2018,11(2): 190-197.

DOI: http://dx.doi.org/10.20902/IJPTR.2018.11209 


\section{Introduction}

Cancer is a degenerative disease that the number of patients increased significantly every year. Cancer is caused by the accumulation of mutations in several related genes that regulates cell proliferation. ${ }^{1}$ Under normal conditions, the process of proliferation and apoptosis is in a balance state and controlled strictly. In cancer, cells could fulfill their growth signal and evade apoptosis. Mutations in certain DNA causes imbalance of apoptosis and proliferation so that cells divide uncontrollably and become mass of malignant cells. ${ }^{2,3,4}$

Normally, our body has a defense mechanism to prevent cancer, yet condition of immune system sometimes weakened, either due to often exposure to infection, pollutants and carcinogens, or malnourished. ${ }^{5}$ Immunocompromise individuals are susceptible to cancer due to impaired immune function to recognize potentially cancer cells, even immunosuppression often precede the growth of tumors. ${ }^{2}$ Thus administration of immunomodulatory compound could enhance immune function in preventing the growth of cancer cells.

Currently, researchers are focusing on organisms that appear to offer anti cancer and immune system enhancing activity. Some types of fungi and it's extract has antitumor properties which are mainly derived from polysaccharides such as beta glucan or complex polysaccharides - proteins (proteoglycans). ${ }^{6}$ Beta glucan is a polysaccharide isolated from the cell walls of fungi, molds, oats, barley, seaweed, algae and bacteria. Beta glucan, is a polysaccharide composed of $\mathrm{D}$-glucose with $\beta$-glycosidic bonding. ${ }^{7}$ This active compound may stimulate non-specific immune system and showed antitumor activity by modulate the immune mechanisms in the body. Beta glucan could activate effector cells such as macrophages, lymphocytes $\mathrm{T}$ cells and NK cells to secrete cytokines such as TNF- $\alpha$, IFN- $\gamma$, IL- $1 \beta$ and others that are able to inhibit proliferation, induce apoptosis and differentiation of tumor cells. ${ }^{6,8}$ These immunomodulating properties protect the host to infections and neoplasms. ${ }^{10}$ Antitumor properties of mushroom's beta glucan are varied depend on the fungal species, molecular weight, structure, solubility, types of glycosidic bond and conformation forms of polysaccharides chain. ${ }^{6,7,9}$

The efficacy of active polysaccharides beta glucan from several types of mushrooms such as Coriolus versicolor, Lentinus edodes, Ganoderma lucidum, Schyzophyllum sp, for antitumor or anticancer has been well documented both in vitro and in vivo. ${ }^{11,12,13}$ However, there are no report about the anticarcinogenic activity of beta glucan extracted from oyster mushroom's which cultivated at Indonesian local farrm towards breast cancer. This paper was conducted to study the activity of beta glucan extracted from cultivated oyster mushrooms in inhibiting carcinogenesis of breast cancer in rats induced with carcinogen 7.12 Dimethylbenz $(\alpha)$ anthracene (DMBA).

\section{Experimental}

\section{Samples}

Beta glucan sample extracts were obtained from the Laboratory of Mycology, Center for Bioindustrial Technology, Agency for the Assessment and Application of Technology (BPPT). Beta glucan extracts were given in the form of suspension of $0.5 \% \mathrm{CMC}-\mathrm{Na}$.

\section{Experimental animals}

Female Sprague-Dawley rats aged 5 - 6 weeks were obtained from Food and Drug Administration Agency. The rats were randomly arranged to four animals per plastic cages on wood chip bedding with free access to water and food under controlled temperature $\left( \pm 22{ }^{\circ} \mathrm{C}\right.$ ), humidity $(60 \pm 10 \%)$, and lighting (a 12-hr light/dark cycle) conditions. The commercial diet for rats were supplied from Department of Poultry, Bogor Agricultural Institute. All animals were held for a one-week acclimatization period before study commencement. The animals were handled following standard ethical procedures approved by the Animal Experiment Ethic Committee of Ministry of Health.

\section{In vivo study of beta glucan in experimental rats}

Induction of mammary carcinoma in experimental rats were carried out by oral feeding of chemical carcinogen 7.12 Dimethylbenz $(\alpha)$ anthracene (DMBA) at $20 \mathrm{mg} . \mathrm{kg}^{-1}$ dissolved in corn oil $\left(2 \mathrm{mg} . \mathrm{mL}^{-1}\right)$. DMBA induction were given twice a-week for 5 times according to the methods reported by Agustini 
(2012). ${ }^{14}$ Oral administration of beta glucan were carried out for about 28 weeks, a week after last induction of DMBA. Grouping of experimental rats were described as indicated in Table 1.

Table 1. Group of treatment in DMBA induced rats

\begin{tabular}{ll}
\hline \multicolumn{1}{c}{ Group } & \multicolumn{1}{c}{ Treatment } \\
\hline Control (Normal) & Standard diet \\
& \\
DMBA & Standard diet and DMBA 20 mg kg-1(*) \\
P 0.25 & Standard diet, DMBA 20 mg kg-1 and beta glucan $0.25 \mathrm{~g} \mathrm{~kg}^{-1(*)}$ \\
P 1.00 & Standard diet, DMBA 20 mg kg and beta glucan $1.00 \mathrm{~g} \mathrm{~kg}^{-1}(*)$ \\
\hline
\end{tabular}

(*) induction of DMBA and administration of beta glucan were based on kg body weight

\section{Observations of tumor nodules}

The development of tumor nodules were observed by monitoring tumor incidence, total volume and total number of tumor weekly. The incidence of tumor growth was calculated based on the percentage of rats with nodul in each group. The total volume of tumor nodules per group were calculated as the total number of volume of tumor nodules through out the group. Tumor nodules volume calculated by using the formula as followed: $\mathrm{V}=4 / 3 \pi$. (d1), (d2), where $\mathrm{V}=$ volume of tumor, $\pi=22 / 7, \mathrm{~d} 1=$ diameter of tumor horizontally, $\mathrm{d} 2$ $=$ diameter of the tumor vertically. ${ }^{15}$ The total number of tumors in each group were calculated as the number of tumor nodules in each group.

\section{Histopathology analysis}

Necropsy followed with euthanasia were carried out at the end of experiment. All tumors were removed from each rats, washed with $0.9 \% \mathrm{NaCl}$, fixed in $10 \%$ buffered formaldehyde solution then processed through to paraffin embedding. All paraffin-embedded tissues were cut at $4 \mu \mathrm{m}$ thickness followed with hematoxylin and eosin (HE) staining for histopathological examination. Tumor histopathology analysis was performed by using score of the severity of the tumor as explained in Elston and Allison. ${ }^{16,17}$

\section{Statistical Analysis}

The data obtained from this study are presented as images, tables and graphs. All data were analyzed using one way ANOVA followed with post-hoc LSD test for significant difference between groups with SPSS software. Significance level was set at $\mathrm{p}<0.05$.

\section{Result}

\section{Effect of beta glucan on the development of tumor nodules}

The effect of beta glucan on the inhibition of carcinogenesis of breast tumor were indicated in Fig. 1, Fig. 2 and Fig. 3. Figure 1 shows the effect of beta glucan administration on the incidence of tumors.

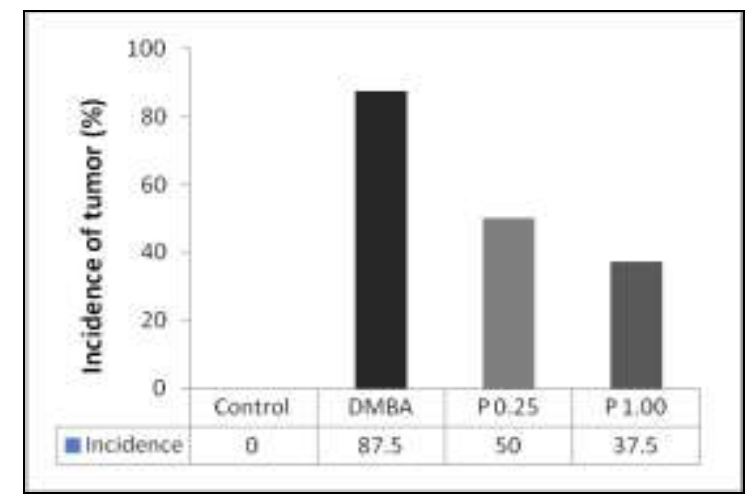

Figure 1. Effect of $\beta$-glucan on the incidence of tumors. Incidence shows the percentage of tumor nodules in rats in each group. Administration of beta glucan tend to decrease tumor incidence 
The result showed that most of rats in DMBA gorup developed tumor, on the other hand supplementation of $\beta$-glucan seems to reduce the risk for tumor incidence in dependent manner, in which $\mathrm{P}$ 1.00 group show the lowest incidence of tumor (Figure 1). The effect of beta glucan on the total volume of tumor was indicated in Figure 2.

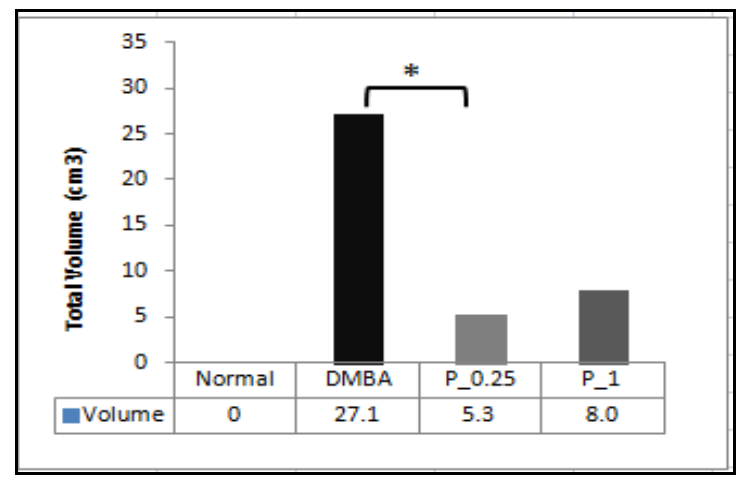

Figure 2. Effect of $\beta$-glucan on the total volume of tumors. Administration of beta glucan significantly reduced total volume of tumors $(p<0.05)$ in beta glucan treated group at dose of $0.25 \mathrm{~g} \mathrm{~kg}^{-1}$

Significant reduction of total volume of tumor were seen at $\mathrm{P} 0.25$ group $(\mathrm{p}<0.05)$ rather than $\mathrm{P} 1$ ( $\mathrm{p}$ $>0.05$ ). It revealed that beta glucan extract at dose of $0.25 \mathrm{~g} \mathrm{~kg}^{-1}$ body weight give the best suppression on tumor growth. Meanwhile effect of beta glucan on the total number of tumor was presented in Figure 3.

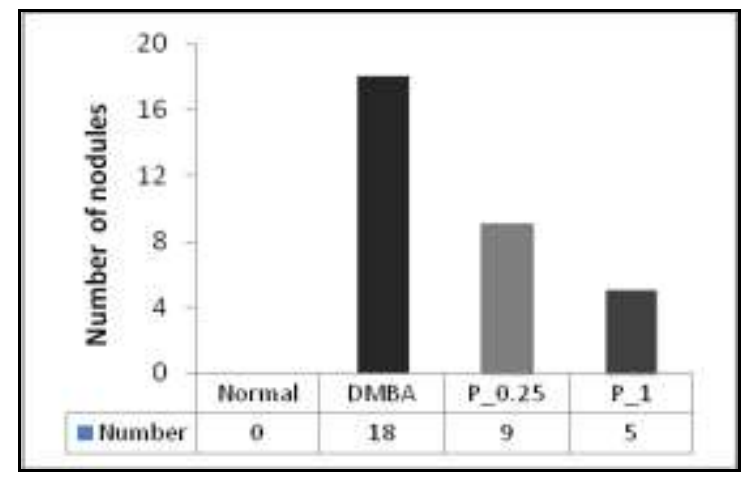

Figure 3. Effect of $\beta$-glucan on the total number of tumor nodules. Total number of nodules indicate the total number of tumor nodules in each group. Administration of beta glucan could reduced the total number of tumor

Although there was no significant difference in each group ( $p>0.05$ ), however total number of tumor in beta glucan-treated group tends to decrease compared with DMBA group. Total number of tumor in DMBA, $\mathrm{P} 0.25$ and $\mathrm{P} 1.00$ group were 18,9 and 5 tumors respectively.

\section{Histopathological analysis}

Histopathological analysis of mammary tissue were indicated in Figure 4 and Table 2. Scoring system described in Agustini, ${ }^{14}$ Elston and Ellis ${ }^{16}$ were adopted for histopathological analysis of the mammary tissue of experimental animals. There were no significant difference in tumor severity score in each group ( $p>$ 0.05), however the score tend to decrease in beta glucan treated group rather than DMBA group. Mean score of tumor severity of DMBA, P 0.25 and P 1.00 were 3.3, 2.4 and 2.8 respectively. 


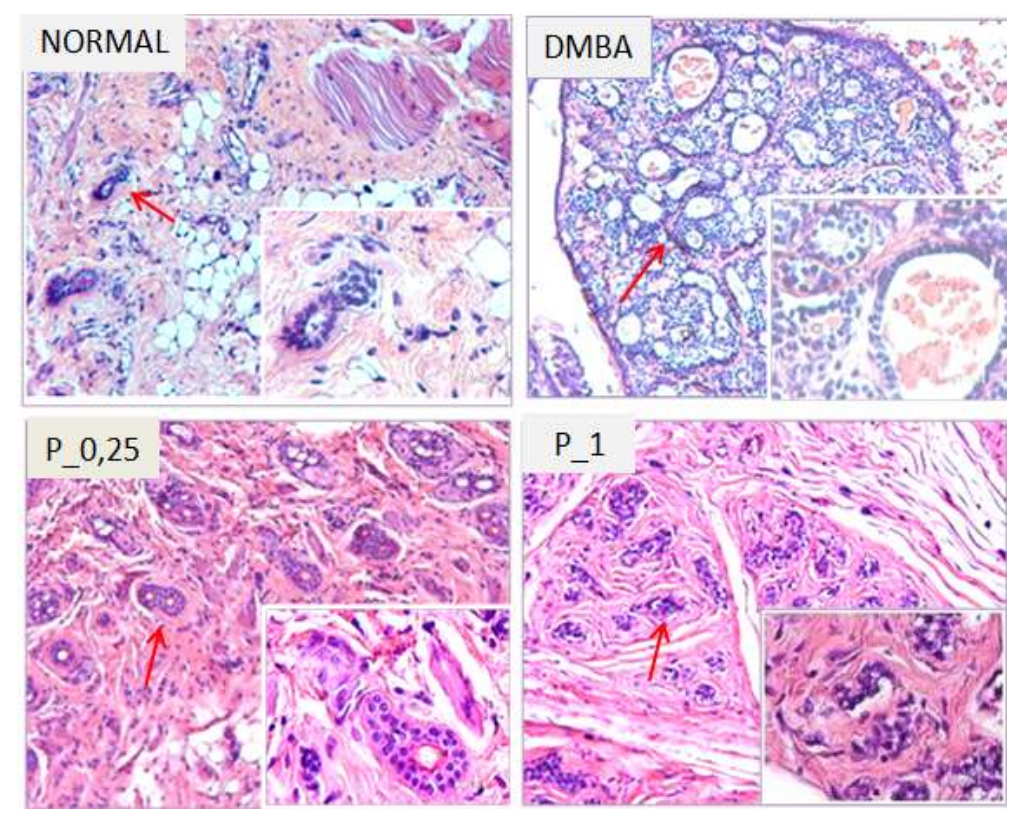

Figure 4. Histopathologic features of rat mammary tissues in all treatment groups. Normal group: no tissue disorders; DMBA group, cell proliferation occurs massively, DCIV criteria; $\beta$-glucan treated group $P$ o.25 $(0.25 \mathrm{~g} / \mathrm{kg}$ ) and $P 1.00$ (dose of $1 \mathrm{~g} / \mathrm{kg}$ ) began a proliferation, hyperplasia criteria. Arrows indicate ductus. Magnification 100x, (insert: 400x).

Table 2. Histopathological analysis of tumor tissues

\begin{tabular}{|c|c|c|c|c|c|}
\hline Code & Group & Scoring & & $\begin{array}{l}\text { Mean } \\
\text { Score }\end{array}$ & $\begin{array}{c}\text { Tumor } \\
\text { severity }\end{array}$ \\
\hline \multirow[t]{5}{*}{ Normal } & Control group & 1 & Normal & 1 & Normal \\
\hline & & 1 & Normal & & \\
\hline & & 1 & Normal & & \\
\hline & & 1 & Normal & & \\
\hline & & 1 & Normal & & \\
\hline \multirow[t]{6}{*}{ DMBA } & DMBA group & 4 & DCIS & & DCIV, Grade I \\
\hline & & 2 & Hyperplasia & 3.3 & \\
\hline & & 5 & DCIV, $\mathrm{T}=2, \mathrm{~N}=2, \mathrm{M}=1$, Total $=5$, Grade $\mathrm{I}$ & & \\
\hline & & 5 & $\mathrm{DCIV}, \mathrm{T}=2, \mathrm{~N}=2, \mathrm{M}=1$, Total $=5$, Grade $\mathrm{I}$ & & \\
\hline & & 2 & Hyperplasia & & \\
\hline & & 2 & Hyperplasia & & \\
\hline \multirow[t]{5}{*}{ P 0.25} & Beta glucan & 1 & Normal & & DCIV, Grade II \\
\hline & $0.25 \mathrm{~g} \mathrm{~kg}^{-1}$ & 5 & DCIV, $\mathrm{T}=2, \mathrm{~N}=2, \mathrm{M}=2$, Total $=6$, Grade II & 2.4 & \\
\hline & & 2 & Hyperplasia & & \\
\hline & & 2 & Hyperplasia & & \\
\hline & & 2 & Hyperplasia & & \\
\hline \multirow[t]{5}{*}{ P 1.00} & Beta glucan & 1 & Normal & & DCIV, Grade I \\
\hline & $1.00 \mathrm{~g} \mathrm{~kg}^{-1}$ & 1 & Normal & 2.8 & \\
\hline & & 5 & DCIV, $\mathrm{T}=2, \mathrm{~N}=2, \mathrm{M}=1$, Total $=5$, Grade $\mathrm{I}$ & & \\
\hline & & 5 & DCIV, $\mathrm{T}=1, \mathrm{~N}=1, \mathrm{M}=3$, Total $=3$, Grade $\mathrm{I}$ & & \\
\hline & & 2 & Hyperplasia & & \\
\hline
\end{tabular}

Criteria of scoring ${ }^{14,16}$ :

$1=$ Normal tissue

2 = Hyperplasia

3 = Hyperplasia atypia, epithelium cells proliferated and expanded, abnormal pattern of growth is seen, lots of polinuclei cells

$4=$ Ductal Carcinoma in Situ (DCIS)

$5=$ Ductal Carcinoma invasive (DCIV) 


\section{Discussion}

DMBA is procarcinogen compound that will change into an active metabolite (epoxide compound) which is very reactive after metabolized by cytochrome P-450 in lever. ${ }^{18}$ Furthermore, the compound formed a covalent bonding with DNA (DNA adducts) in the group of guanine $(\mathrm{G})$, which causes DNA lesions which in turn will trigger the growth of neoplasms if it could not be repair in the process of DNA repairment. ${ }^{15}$ When a permanent DNA lesions occured, it would change gene expression which are recognized as an antigen by the immune cells. ${ }^{5}$

At the initiation and early stages of cancer promotion, beta glucan acts as an immunomodulator which can improve the function of the immune system that mediate defenses against tumor (immune surveillance) by enhancing the sensitivity of innate immune cells such as macrophage, granulocyte and NK cells to detect tumor antigen. According to Cheung-VKN et al, who labelled $\beta$-glucan in order to track these molecules path inside the body, beta glucan were uptake by macrophages via the Dectin-1 receptor in the digestion system and was subsequently transported to the spleen, lymph nodes and bone marrow. In the bone marrow, macrophages degraded the large $\beta$-1,3-glucans into smaller soluble $\beta-1,3$-glucan fragments. These fragments were then taken up through complement receptor 3 (CR3) of marginated granulocytes. These granulocytes with CR3-bound $\beta$-glucan were shown to kill inactivated complement $3 b$ (iC3b)opsonized tumor cells after they were recruited to a site of complement activation such as tumor cells coated with monoclonal antibody. ${ }^{19}$

In this research it was demonstrated that supplementation of beta glucan in rats induced by DMBA could suppressed of tumor growth. ${ }^{5}$ Suppression of tumor growth were represented by lower tumor incidence, total volume and total number of tumors in beta glucan supplemented group compare to that of DMBA group. Incidence of tumor in DMBA group was the highest $(87.5 \%)$ compare to beta glucansupplemented group (50\% and 37,5\% for P 0.25 and $\mathrm{P} 1.00$ group respectively) (Fig.1). The highest total volumes of tumor were obtained in DMBA group $\left(27.1 \mathrm{~cm}^{3}\right)$ while the lowest were at P 0.25 group (5.3 $\mathrm{cm}^{3}$ ) (Fig. 2). On the other hand the highest total number of tumors were at DMBA group (18 nodules) while the lowest were at P 1.00 group (5 nodules) (Fig. 3). It appears that beta glucan extract at dose of $0.25 \mathrm{~g}$ $\mathrm{kg}^{-1}$ bw give a better suppression on tumor growth rather than $\mathrm{P} 1.00$. Beta glucan also inhibit tumor cell proliferation significantly, in which proliferation index was lower than DMBA group. ${ }^{5}$

The effect of beta glucan supplementation to suppress tumor growth was also confirmed in hystopathological analysis of mammary tumor. Mean score of tumor severity of DMBA, P 0.25 and P 1.00 groups were 3.3, 2.4 and 2.8 respectively. Though there were no significant difference in tumor severity score in each group ( $\mathrm{p}>0.05)$, however beta glucan-supplemented group have lower tumor severity score than DMBA group (Table 2). Histopathological analysis of mammary tissue showed that there were DCIV criteria in each group with different number of cases. In beta glucan-supplemented group, some rats were still observed in normal condition and did not develop mammary tumor, while the others were in hyperplasia condition. These group also have less tumor nodules when tumor evacuation were carried out at the end of the research, indicating that administration of beta glucan could favorably useful to suppress tumor growth in DMBA induced rats. ${ }^{5}$

The mechanism underlying antitumor effect of beta glucan is due to their activity to activate effector cells such as macrophages, lymphocytes T cells and NK cells to secrete cytokines such as TNF- $\alpha$, IFN- $\gamma$, IL$1 \beta$ and others that are able to inhibit proliferation and induce apoptosis of tumor cells. ${ }^{6,7}$ As a part of first line defense, macrophage also released pro inflamatory cytokine, expressed MHC molecules and released iNOs that killed tumor cells. It has been demostrated also in this research that beta glucan modulate innate immune system by inducing macrophage to release nitric oxide (NO) and TNF- $\alpha$ which suppress tumor growth (data not shown). ${ }^{5}$ This finding was in line with Sarangi, ${ }^{20}$ who studied that crude and fraction extract of Pleurotus ostreatus demonstrated anticancer activity by inducing macrophage to release nitric oxide (NO) on Sarcoma-180-bearing mouse model. 


\section{Conclusion}

Beta glucan, a polysaccharide composed of D - glucose with $\beta$-glycosidic bonding which in this research was isolated from the cell walls of oyster mushroom (Pleurotus ostreatus), has anti tumor activity toward DMBA-induced breast cancer on female Sprague-Dawley rats. Antitumor activity is due to the activation of innate immunity such as macrophage which mediated by $\mathrm{TNF}-\alpha$ and $\mathrm{NO}^{5}$ resulting on supression of tumor growth as seen by lower tumor volume and amount of tumor nodules in beta glucan supplemented group.

\section{References:}

1. Kresno, S. B. Karsinogenesis. Ilmu Dasar Onkologi. Jakarta: Badan Penerbit Fakultas Kedokteran Universitas Indonesia. 2011. p. 112 - 129.

2. Kresno, S. B. Kankerdan SistemImun. Ilmu Dasar Onkologi. Jakarta: Badan Penerbit Fakultas Kedokteran Universitas Indonesia. 2011. p. 284 - 312.

3. Meiyanto, E. Biologi Molekuler. Materi Kuliah Workshop Molecular Biology On Cancer. CCRC Universitas GadjahMada, Yogyakarta. 2011. p. 23 - 27.

4. Weinberg, R. A. Tumor suppressor genes. In: The Biology of Cancer. New York: Garland Sc. 2007. p. 209 -254.

5. Susanti, I. Efek $\beta$-Glukandari Jamur Tiram (Pleurotusostreatus, Jacq. P. Kum) Sebagai Antikanker Payudara Alami: Studi Imunostimulasidan Antiproliferasi Pada Tikus. Disertasi. 2015. FakultasKedokteranUniversitas Indonesia. p.89- 97.

6. Lindequist U, Niedermeyer HJ, Jullich WD. (2005). The pharmacological potential of mushrooms. eCAM2, 3, 285-299.

7. Borchers, A. T., Krishnamurthy, A., Keen, C. L., Meyers, F. J., \& Gershwin, M. E. (2008). The Immunobiology of mushrooms. Experimental Biology and Medicine, 233(3), 259-276. doi:10.3181/0708-MR-227.

8. Jedinak A and Daniel Sliva. (2008). Pleurotusostreatus inhibits proliferation of human breast and colon cancer cells through p53-dependent as well as p53-independent pathway, International Journal of Oncology, 33, 1307 - 1313.

9. Carbonero, E. R., Gracher, A. H. P., Smiderle, F. R., Rosado, F. R., Sassaki, G. L., Gorin, P. A. J., \& Iacomini, M., (2006). A $\beta$-glucan from the fruit bodies of edible mushrooms Pleurotus eryngii and Pleurotus ostreatoroseus. Carbohydrate Polymers, 66(2), 252-257. doi:10.1016/j.carbpol.2006.03.009.

10. Di Luzio, N. R. "Update on the immunomodulating activities of glucans". Springer seminars in immunopathology. Germany: Springer Verlag. 1985. 8 (4): 387400. doi: 10.1007/BF01857392. PMID 4089757.

11. Hozova, B., Kuniak, L., Moravcikova, P., \& Gajdosova, A. (2008). Determination of water-insoluble $\beta$-D-glucan in the whole-grain cereals and pseudocereals. Czech Journal of Food Sciences, 25(6), 316324. doi:10.17221/747-CJFS.

12. Manzi, P., \& Pizzoferrato, L. (2000). Beta-glucans in edible mushrooms. Food Chemistry, 68(3), 315318. doi:10.1016/S0308-8146(99)00197-1.

13. Gregori, A., Svagelj, M., \& Pohleven, J. (2007). Cultivation techniques and medicinal properies of Pleurotusspp. Food Technology and Biotechnology, 45(3), 238-249.

14. Agustini K. Isolasidankarakterisasisenyawaaktifsertaeksplorasiaktivitas in vitro dan in vivo bijiklabet (Trigonellafoenum-graecum L.) sebagai SERMs (Selective Estrogen Receptor Modulator) Alamiah.Disertasi. 2012,FakultasKedokteranUniversitas Indonesia.

15. Wibowo AE. Aktivitasantikankerdaunlabanabang(AglaiaellipticaBlume):ekstraksi, identifikasisenyawa, uji in vitro dan in vivo. Disertasi. 2010,Fakultas Kedokteran Universitas Indonesia.

16. Elston CW dan Ellis IO. (1991). Pathological prognostic factors in breast cancer I. The value of histological grade in cancer breast: experience from a large stude with long term follow up.//www.Breastpathology.info/ Grading.html.. Histopathology, 19, 403-410. 
17. Ting, A. Y., Kimler, B. F., Fabian, C. J., \& Petroff, B. K. (2007). Characterization of a preclinical model of simultaneous breast and ovarian cancer progression. Carcinogenesis, 28(1), 130-135. doi:10.1093/carcin/bgl140.

18. Lin, C.-C., Lu, Y.-P., Lou, Y.-R., Ho, C.-T., Newmark, H. H., MacDonald, C., \& Huang, M.-T., (2001). Inhibition by dietary dibenzoymethane of mammary gland proliferation, formation of DMBADNA adduct in mammary glands amd mammary tumorigenesis in Sencar Mice. Cancer Letters, 168(2), 125-132. doi:10.1016/S0304-3835(01)00506-7.

19. Hong, F., Yan, J., Baran, J. T., Allendorf, D. J., Hansen, R. D., Ostroff, G. R., \& Ross, G. D. (2004). Mechanism by which orally administered beta-1,3-glucans enhace the tumoricidal activity of antitumor monoclonal antibodies in murine tumor models. Journal of Immunology (Baltimore, Md.: 1950), 173(2), 797-806. doi:10.4049/jimmunol.173.2.797.

20. Sarangi, I., Ghosh, D., Bhutia, S. K., Mallick, S. K., \& Maiti, T. K. (2006). Anti tumor and immunomodulating effects of Pleurotusostreatus mycelia-derived proteoglycans. International Immunopharmacology, 6(8), 1287-1297. doi:10.1016/j.intimp.2006.04.002. 
